\title{
Polymer Electrolyte Membrane Fuel Cell Performance of a Sulfonated Poly(Arylene Ether Benzimidazole) Copolymer Membrane
}

\author{
Hasan Ferdi Gerçel, Çağla Gül Tosun, and Levent Akyalçın \\ Department of Chemical Engineering, Anadolu University, 26555 Eskisehir, Turkey \\ Correspondence should be addressed to Hasan Ferdi Gerçel; hfgercel@anadolu.edu.tr
}

Received 6 June 2016; Revised 24 October 2016; Accepted 25 October 2016

Academic Editor: Gianluca Cicala

Copyright (C) 2016 Hasan Ferdi Gerçel et al. This is an open access article distributed under the Creative Commons Attribution License, which permits unrestricted use, distribution, and reproduction in any medium, provided the original work is properly cited.

\begin{abstract}
Disodium-3,3'-disulfonate-4, $4^{\prime}$-dichlorodiphenylsulfone (SDCDPS) and 5,5'-bis[2-(4-hydroxyphenyl)benzimidazole] (HPBI) monomers were synthesized. Binding these monomers via nucleophilic aromatic polycondensation reaction, a sulfonated poly(arylene ether benzimidazole) copolymer was synthesized. Structures of monomers and copolymer were confirmed by proton nuclear magnetic resonance spectroscopy $\left({ }^{1} \mathrm{H}\right.$ NMR) and Fourier transform infrared (FTIR) spectroscopy analyses. Proton exchange membrane was prepared by dissolving copolymer in dimethylacetamide (DMAc) and casting onto a glass plate. Copolymer membrane was doped with sulfuric acid to ensure proton exchange character. Single cell performance of the copolymer membrane was tested in a polymer electrolyte membrane fuel cell test station. The highest power density of the membrane was measured as $23.7 \mathrm{~mW} \mathrm{~cm}^{-2}$ at $80^{\circ} \mathrm{C}$. Thermogravimetric analysis (TGA) showed that as the degree of disulfonation is increased thermal stability of the copolymer is increased.
\end{abstract}

\section{Introduction}

Environmental challenges of fossil fuel use, effects of harmful emissions on human health, and dependence of industrial nations on oil that leads to oil crises have induced the development of fuel cell technologies in past 25 years $[1,2]$. Fuel cells are considered to be the solution of environmentally friendly and highly efficient electrical energy production of the future. Among fuel cell types, polymer electrolyte membrane fuel cells (PEMFCs) attract most attention due to their high power density, high energy transformation efficiency, and wide range of applications in stationary and portable devices $[3,4]$. Perfluorosulfonic acid based polymer membranes such as Nafion ${ }^{\circledR}$ are considered as state-of-the-art membranes and used frequently in PEMFCs owing to their outstanding chemical and physical stabilities and high proton conductivity at moderate operating temperatures. However, studies on development of alternative polymer electrolyte membranes continue because of the drawbacks of Nafion membranes like decrease in proton conductivity at temperatures above $80^{\circ} \mathrm{C}$ due to dehydration, humidification requirement, and high prices [5-7].

Studies about polymer based sulfonated proton exchange membrane materials such as poly(arylene ether sulfone)s [811], poly(ether ether ketone)s [12-14], poly(arylene thioether) [15-17], poly(phenylene)s [18-20], polyimides [21-24], and other types of polymers have largely taken place in the scope of polymer electrolyte membrane researches so far.

Polybenzimidazole (PBI) membranes doped with strong acids predominate over other proton exchange membranes due to their stable proton conductivity at temperatures higher than $100^{\circ} \mathrm{C}$. However, synthesis of high molecular weight PBI polymer is difficult and cost is quite high. Besides, dissolution of PBI in common organic solvents is difficult due to its rigid molecular structure. On the other hand, synthesis of poly(arylene ether sulfone)s is easier and cost is lower. However, they have low mechanical stability due to water swelling and dissolution of the poly(arylene ether sulfone) membranes in 
water that limits their practical applications [6, 7]. In this study, a sulfonated poly(arylene ether benzimidazole) copolymer was synthesized [25-30] and a copolymer membrane was prepared by solution casting method. The membrane was treated with sulfuric acid to strengthen the proton conductivity character. Finally single cell performance of the copolymer membrane was tested in a PEMFC test station.

\section{Experimental}

2.1. Materials. $4,4^{\prime}$-Dichlorodiphenyl sulfone (DCDPS) and 4-hydroxybenzoic acid phenyl ester were purchased from $\mathrm{ABCR}$ and vacuum dried at $50^{\circ} \mathrm{C}$ for $24 \mathrm{~h}$ before use. Fuming sulfuric acid (65\% $\mathrm{SO}_{3}$, extra pure), phenylsulfone, and 1methyl-2-pyrrolidone (+99.5\%) were used as received from Merck. Sodium chloride, $3,3^{\prime}$-diaminobenzidine (DAB), and DMAc were purchased from Sigma Aldrich. DAB was vacuum dried at $50^{\circ} \mathrm{C}$ for $24 \mathrm{~h}$ before use. Sodium hydroxide, toluene, and isopropanol were used as received from Riedel de Haen. Potassium carbonate (Alfa AESAR) was vacuum dried at $50^{\circ} \mathrm{C}$ for $24 \mathrm{~h}$ prior to use. Sulfuric acid (95-97\%) was used as received from Fluka.

2.2. Synthesis of Monomers. Synthesis of HPBI has been previously reported by several researchers $[29,30]$. DAB (0.467 mole), 4-hydroxybenzoic acid phenyl ester $(0.934 \mathrm{~mole})$, phenylsulfone $(500 \mathrm{~g})$, and toluene $(150 \mathrm{~mL})$ were added to a jacketed four-necked cylindrical reactor equipped with a Dean-Stark trap, a condenser, a mechanical stirrer, and a nitrogen inlet-outlet. Reaction temperature was controlled by oil bath circulator. Reactor was isolated to prevent heat loss. Dean and Stark trap was filled with toluene to remove water azeotropically. Temperature was raised to $150^{\circ} \mathrm{C}$ and the solution was allowed to reflux for 6 hours. Toluene was removed and the solution was heated to $280^{\circ} \mathrm{C}$ for $2 \mathrm{~h}$. Generated water and phenol were removed from Dean and Stark trap and the monomer precipitated. For further removal of phenol, outlet gas stream was connected to two serial gas washing bottles and vacuum was applied for 2 hours. Solution was left to cool and excess ethanol was added at $150^{\circ} \mathrm{C}$. Product was left at room temperature overnight and filtered to separate the phenylsulfone that crystallized out of solution. Synthesized tan monomer was washed with acetone and dried at $120^{\circ} \mathrm{C}$ for 24 hours.

$3,3^{\prime}$-Disulfonated- $4,4^{\prime}$-dichlorodiphenyl sulfone (SDCDPS) monomer [30-33] synthesized in a four-necked round bottom flask equipped with a thermometer, a condenser, a mechanical stirrer, and a nitrogen inlet-outlet. DCDPS $(99 \mathrm{mmol})$ was dissolved in fuming sulfuric acid $\left(65 \% \mathrm{SO}_{3}\right)$. Temperature was raised to $110^{\circ} \mathrm{C}$ and the mixture was stirred for 6 hours to produce a homogeneous solution. Then solution was cooled to room temperature and sodium chloride was added. The dark brown color of the solution turned into white and the product was neutralized to $\mathrm{pH}$ 6-7 with sodium hydroxide and excess sodium chloride was added to precipitate the monomer as its sodium form. Synthesized SDCDPS was filtered, recrystallized from isopropanol and water mixture for further purification. Resulted white monomer dried at $120^{\circ} \mathrm{C}$ for 24 hours.

\subsection{Disulfonated Poly(Arylene Ether Benzimidazole) (SPAEB)} Copolymers Synthesis. Einsla has previously reported the synthesis of disulfonated poly(arylene ether benzimidazole) copolymer [30]. SDCPS (7 mmol) and equimolar DCDPS and HPBI $(14 \mathrm{mmol})$ were introduced into a $250 \mathrm{~mL}$ fournecked flask equipped with a thermometer, mechanical stirrer, a Dean-Stark trap, a condenser, and a nitrogen inletoutlet. Potassium carbonate $(16 \mathrm{mmol})$ and $75 \mathrm{~mL}$ of NMP were introduced to the reaction flask. As an azeotroping agent $40 \mathrm{~mL}$ of toluene was introduced to the flask and the DeanStark trap was filled with toluene. Temperature was raised to $140^{\circ} \mathrm{C}$ for dehydration of the system for 4 hours and Dean and Stark trap was emptied. Temperature was raised to $170^{\circ} \mathrm{C}$ and reaction was carried out for 20 hours. Generated toluene during reaction was removed via Dean and Stark trap. The dark brown viscous solution poured into deionized water and the precipitated copolymer was filtered. The yellowish-brown fibrous copolymer was dried at $120^{\circ} \mathrm{C}$ for $24 \mathrm{~h}$ and grounded.

2.4. Postsulfonation of SPAEB Copolymers. A postsulfonation method was used for further sulfonation of synthesized SPAEB copolymers to analyze the effect of degree of sulfonation to thermal stability and proton conductivity. Postsulfonation was carried out by dissolving $5 \mathrm{~g}$ of the copolymer in $100 \mathrm{~mL}$ fuming sulfuric acid (65\%) and stirred for 10 hours at $30^{\circ} \mathrm{C}$. Resulting product was denoted as SPAEB_oleum $\left(\mathrm{SO}_{3} \% 65\right)$. After the reaction, the reaction mixture was poured into a large volume water to precipitate the product. The sulfonated polymer material was recovered and washed with water until the wash was $\mathrm{pH}$ neutral and it was then dried for $48 \mathrm{~h}$ at $100^{\circ} \mathrm{C}$.

2.5. Membrane Preparation and Acid Doping. Synthesized copolymer $(0.75 \mathrm{~g})$ was dissolved in $31.88 \mathrm{~mL}$ of DMAc $\left(2.5 \%, \mathrm{w} \mathrm{w}^{-1}\right)$ in a $250 \mathrm{~mL}$, two-necked flask equipped with a mechanical stirrer, and a condenser. The flask was inserted in an ultrasonic water bath. Temperature was heated to $80^{\circ} \mathrm{C}$ for 4 hours. After filtration, solution was cast onto petri dishes and dried. Resulting transparent membranes were immersed in boiling $0.5 \mathrm{M} \mathrm{H}_{2} \mathrm{SO}_{4}$ for 2 hours and dried to remove absorbed water. The same membrane preparation procedure was performed for SPAEB_oleum $\left(\mathrm{SO}_{3} \% 65\right)$ too.

2.6. Characterization. The ${ }^{1} \mathrm{H}$ NMR spectra of the monomers and copolymer were recorded on a $500 \mathrm{MHz}$ Bruker AVANCE II NMR spectrometer. Grounded monomers and copolymer were dissolved in deuterated dimethylsulfoxide $\left(\right.$ DMSO- $\left.\mathrm{d}_{6}\right)$ and chemical shifts were measured against tetramethylsilane (TMS) as an internal standard. We used the integral area belonging to the protons adjacent to the sulfonate groups and the integral area of the protons next to the carbon of the imidazole moiety degrees of disulfonation obtained from ${ }^{1} \mathrm{H}$ NMR:

Fourier transform infrared (FTIR) spectra were recorded using a Perkin Elmer Frontier spectrometer. All the samples were dried at $105^{\circ} \mathrm{C}$ for $24 \mathrm{~h}$ prior to analyses.

Thermogravimetric curves are largely affected by experimental conditions, especially by the heating rate. So the 


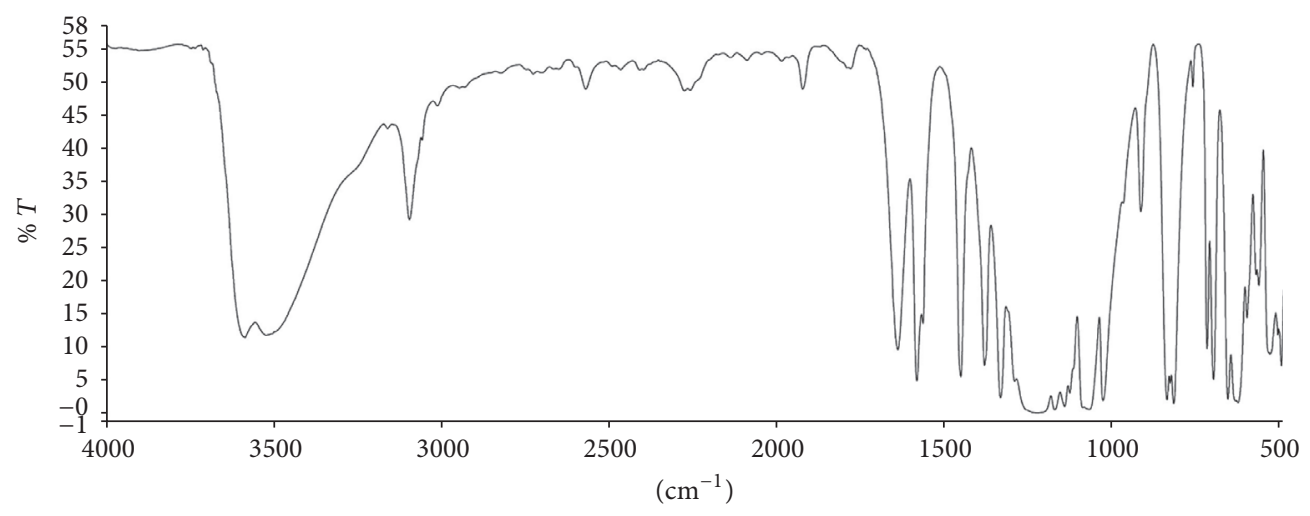

FIGURE 1: FTIR spectrum of SDCDPS.

degradation experiments of samples were carried out at the same scanning rate, $10^{\circ} \mathrm{C} / \mathrm{min}$, because it is a medium scanning rate among those usually employed for thermal degradations $[34,35]$. Thermogravimetric analysis (TGA) was carried out in dynamic heating conditions under flowing nitrogen $\left(100 \mathrm{~mL}^{-1}\right)$ in the temperature range $35-600^{\circ} \mathrm{C}$, using a Netzsch STA 449 F3 thermogravimetric analyzer. Samples of about $9.30 \times 10^{-3} \mathrm{~g}$ for SPAEB and $9.59 \times 10^{-3} \mathrm{~g}$ for SPAEB_oleum $\left(\mathrm{SO}_{3} \% 65\right)$ were used for degradation experiments. Their masses as a function of temperature were monitored and the experimental data were used to plot the percentage of undegraded copolymer as a function of temperature.

A Cannon Ubbelohde dilution viscometer was used to measure inherent viscosity of the copolymer in DMAc at a concentration of $0.5 \mathrm{~g} \mathrm{dL}^{-1}$ at $30^{\circ} \mathrm{C}$.

2.7. Proton Conductivity Measurements. The membrane samples were prepared as rectangular sheets and placed in a Teflon conductivity cell (Bekktech 112) which is connected to four Pt electrodes and the distance between the two inner electrodes was used to measure the potential difference trough the sample. Proton conductivities of the membranes were measured for planar direction sending hydrogen (relative humidity $(\mathrm{RH})=0 \%$ ) into a Scribner 850 fuel cell test system connected to the proton conductivity cell at $80^{\circ} \mathrm{C}$. A Solartron 1287 electrochemical interface was used to measure voltage and current values. Proton conductivity of a sample of commercial Nafion 212 membrane was measured at $80^{\circ} \mathrm{C}$ with $100 \% \mathrm{RH}$ to see the reliability of the results.

2.8. Single Cell Performance Test. The standard fuel cell test station was described elsewhere [36]. Copolymer membrane was sandwiched between the catalyst coated electrodes to produce the membrane electrode assembly. The Pt loadings of cathode and anode were approximately $0.5 \mathrm{mg} \mathrm{cm}^{-2}$. SGL$10 \mathrm{BC}$ was used as gas diffusion layer and the active area of the single cell was $25 \mathrm{~cm}^{2}$. The current and power densities of the fuel cell were recorded. The working temperature of the fuel cell was kept at $80^{\circ} \mathrm{C}$. Hydrogen and oxygen were both fed

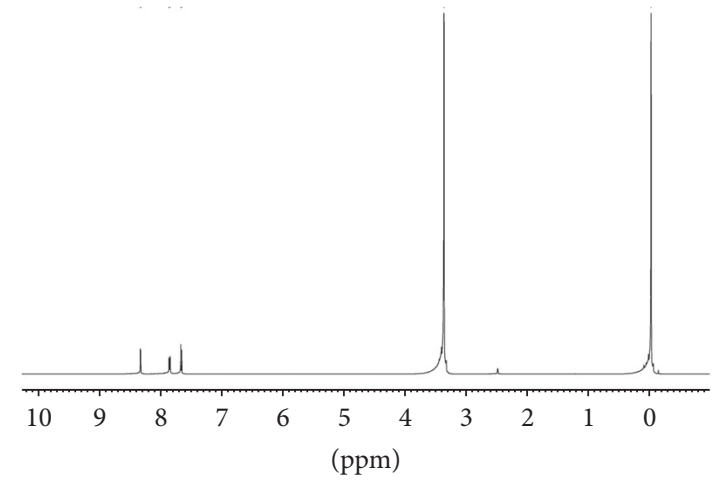

FIgURE 2: ${ }^{1} \mathrm{H}$ NMR spectrum of SDCDPS.

to the fuel cell at a rate of $80 \mathrm{sccm}$ without external humidification at ambient pressure.

\section{Results and Discussion}

3.1. Structural Analysis of SDCDPS. The FTIR spectrum of SDCDPS is shown in Figure 1. C-H stretching of aromatic ring is assigned at $3095 \mathrm{~cm}^{-1}$. The absorption peak at $1638 \mathrm{~cm}^{-1}$ represents the $\mathrm{C}=\mathrm{C}$ stretching vibrations bands. Peaks at $813-824 \mathrm{~cm}^{-1}$ are attributed to the $\mathrm{C}-\mathrm{Cl}$ stretching bands. In-plane bending of aliphatic $\mathrm{C}-\mathrm{H}$ is assigned at $1288 \mathrm{~cm}^{-1}$. Peak observed at $594 \mathrm{~cm}^{-1}$ is due to C-S aromatic ring stretching. The absorption peaks at 1024 and $1084 \mathrm{~cm}^{-1}$ indicates the $\mathrm{S}=\mathrm{O}$ stretching vibrations of sulfonic acid groups. This result confirms the sulfonation of DCDPS.

${ }^{1}$ HNMR spectrum of SDCDPS is shown in Figure 2. The existence of the resonance at $8.34 \mathrm{ppm}$ represents the protons adjacent to the sulfonate groups. This result confirms that the sulfonation of DCDPS was achieved.

3.2. Structural Analysis of HPBI. In the FTIR spectrum of HPBI represented in Figure 3, the large peaks observed at $2500-3200 \mathrm{~cm}^{-1}$ are assigned to $\mathrm{R}_{2} \mathrm{NH}$ stretching vibration and Ar-OH vibration bands. Peaks at $1593 \mathrm{~cm}^{-1}$ 


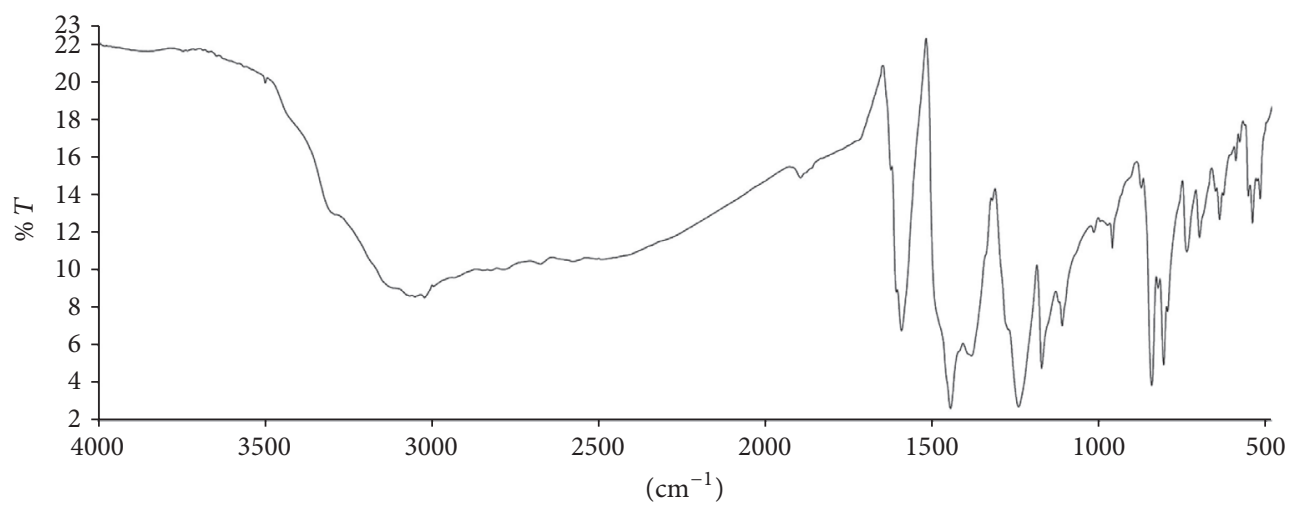

FIGURE 3: FTIR spectrum of HPBI.

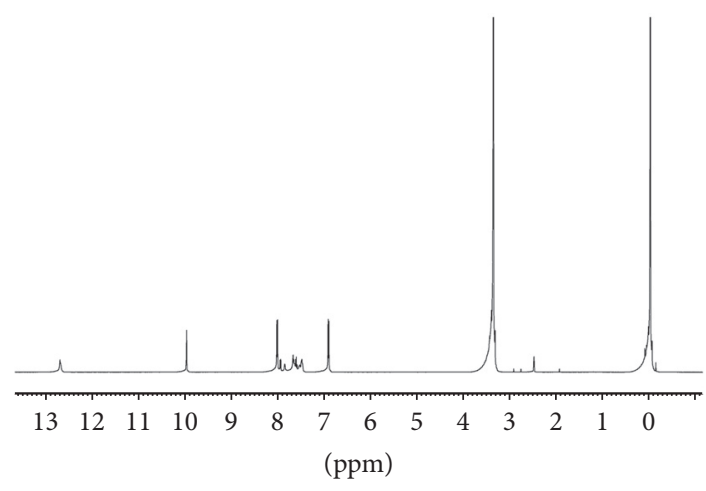

Figure $4:{ }^{1} \mathrm{H}$ NMR spectrum of HPBI.

and $1620 \mathrm{~cm}^{-1}$ show $\mathrm{C}=\mathrm{C}$ stretching and $\mathrm{C}=\mathrm{N}$ stretchingvibration bands (characteristic band of imidazole groups).

Figure 4 shows the ${ }^{1} \mathrm{H}$ NMR spectrum of HPBI. The peak observed at $13.3 \mathrm{ppm}$ is assigned to $\mathrm{N}-\mathrm{H}$ groups. Peak at $10 \mathrm{ppm}$ confirms the existence of the protons of $\mathrm{Ar}-\mathrm{OH}$ groups. This result shows that HPBI monomer synthesis was performed successfully.

3.3. Characterization of Copolymer. Inherent viscosity of the copolymer was measured as $0.92 \mathrm{dL} \mathrm{g}^{-1}$ in DMAc at a concentration of $0.5 \mathrm{~g} \mathrm{dL}^{-1}$ at $30^{\circ} \mathrm{C}$. In FTIR spectrum of sulfonated poly(arylene ether benzimidazole) copolymer shown in Figure 5, peaks at $3000-3500 \mathrm{~cm}^{-1}$ are attributed to the $\mathrm{N}$ $\mathrm{H}$ vibration bands of amide groups. Peaks observed at 1500$1600 \mathrm{~cm}^{-1}$ are due to the aromatic $\mathrm{C}=\mathrm{C}$ and $\mathrm{C}=\mathrm{N}$ stretching bands and they arise from in-plane bending of N-H and conjugation vibration between benzene and imidazole rings. The peak at $1149 \mathrm{~cm}^{-1}$ indicates aromatic sulfone groups. Peaks at $1027 \mathrm{~cm}^{-1}$ and $1243 \mathrm{~cm}^{-1}$ indicate stretching vibration of $\mathrm{O}=\mathrm{S}=\mathrm{O}$ sulfonic acid groups.

Figure 6 shows the ${ }^{1} \mathrm{H}$ NMR spectrum of sulfonated poly(arylene ether benzimidazole) (SPAEB) copolymer. Proton resonances at 7.00, 7.85, and $8.33 \mathrm{ppm}$ confirm that sulfone groups are involved in the structure.
Figure 7 shows ${ }^{1} \mathrm{H}$ NMR spectrum of SPAEB_oleum $\left(\mathrm{SO}_{3} \% 65\right) .{ }^{1} \mathrm{H}$ NMR spectra were also used to evaluate the degrees of disulfonation of SPAEB and SPAEB_oleum $\left(\mathrm{SO}_{3} \% 65\right)$ using a literature method [30] and calculated as

$$
\text { Degree of disulfonation: } 2 \times\left(\frac{H_{a}}{H_{b}}\right) \times 100 \% \text {, }
$$

where $H_{a}$ is the peak which is attributed to the protons adjacent to the sulfonate groups and $H_{b}$ is the peak assigned to protons next to the carbon of the imidazole group located at both the sulfonated and nonsulfonated regions. The degrees of disulfonation for SPAEB and SPAEB_oleum ( $\left.\mathrm{SO}_{3} \% 65\right)$ were calculated as $31 \%$ and $52 \%$, respectively.

3.4. FTIR Analysis and Thermal Behavior of SPAEB Membrane. FTIR spectrum of SPAEB copolymer membrane is shown in Figure 8. Spectrum shows benzimidazole adsorption bands at $1629 \mathrm{~cm}^{-1}, 1584 \mathrm{~cm}^{-1}$, and $1465 \mathrm{~cm}^{-1}$. Peaks at $1025 \mathrm{~cm}^{-1}$ and $1097 \mathrm{~cm}^{-1}$ are assigned to stretching of the sulfonate groups.

TGA curves of the SPAEB and SPAEB_oleum $\left(\mathrm{SO}_{3} \% 65\right)$ copolymer membranes are shown in Figure 9. The first decomposition step around $300^{\circ} \mathrm{C}$ is attributed to the decomposition of the sulfone groups according to the literature [37, 38]. Second thermal degradation steps occurring in temperature ranges $450-500^{\circ} \mathrm{C}$ should be due to polymer main chain. TGA curves reveal that SPAEB copolymer degrades at about $450^{\circ} \mathrm{C}$, whereas the postsulfonated SPAEB_oleum $\left(\mathrm{SO}_{3} \% 65\right)$ copolymer is thermally stable up to $\sim 475^{\circ} \mathrm{C}$. This thermal degradation behavior can be explained with higher percentage of double-bond character due to the increasing number of sulfone groups incorporated in copolymer chain in agreement with the literature $[39,40]$. This result also shows that the presence of sulfonic groups involving strong intra- and intermolecular hydrogen bonds increases thermal stability as in the literature [41].

3.5. Proton Conductivity. The resistance, $R(\Omega)$, of the membranes was calculated as the slope of voltage versus current graphs. Voltage versus current graphs plotted for 30 times to 


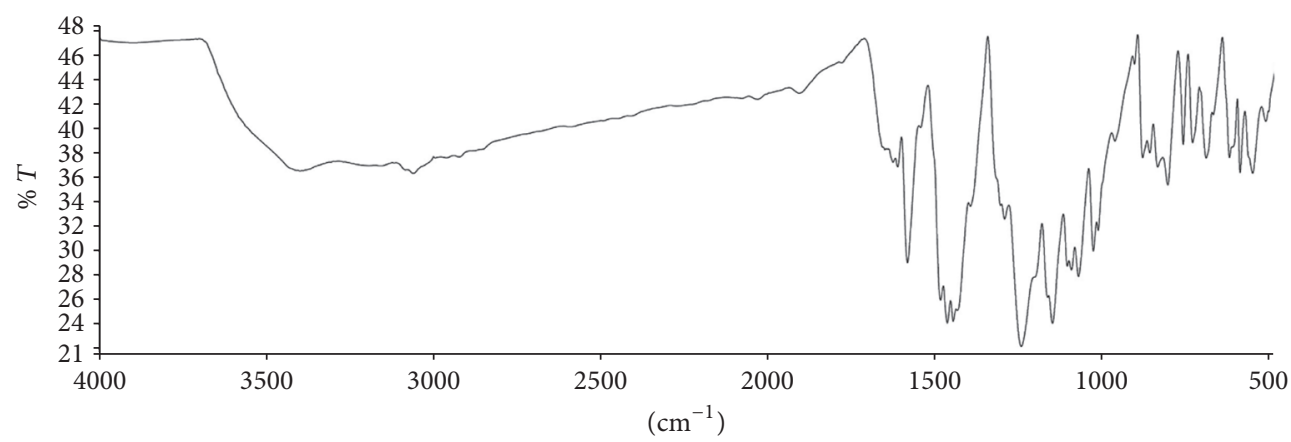

FIGURE 5: FTIR spectrum of sulfonated poly(arylene ether benzimidazole) copolymer.

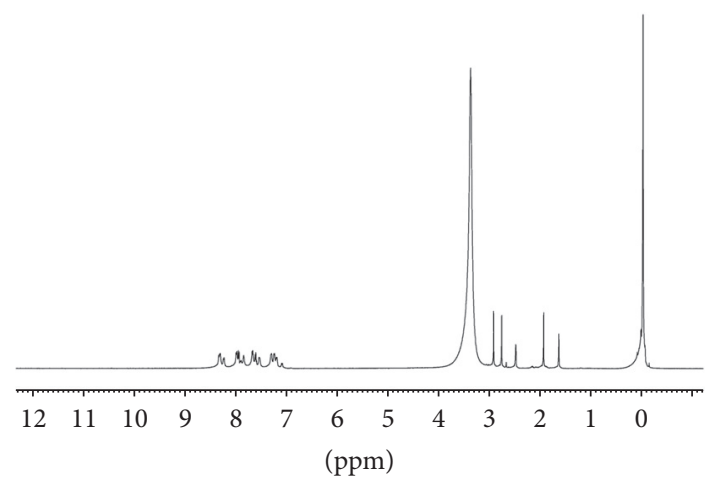

FIgURE 6: ${ }^{1}$ H NMR spectrum of SPAEB copolymer.

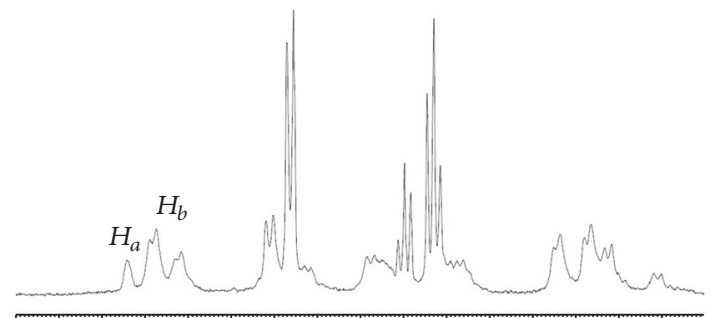

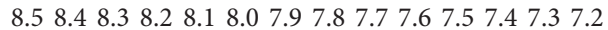

(ppm)

Figure 7: ${ }^{1} \mathrm{H}$ NMR spectrum of SPAEB_oleum $\left(\mathrm{SO}_{3} \% 65\right)$.

reach a stable resistance value for each membrane. Figure 10 shows the voltage versus current graphs of SPAEB_oleum $\left(\mathrm{SO}_{3} \% 65\right)$, SPAEB, and commercial Nafion 212 membranes. The proton conductivity, $\sigma(\mathrm{S} / \mathrm{cm})$, values were calculated from the equation

$$
\sigma=\frac{1}{R} \times \frac{L}{(W \times T)},
$$

where $L(0.425 \mathrm{~cm})$ is the distance between the voltage sense electrodes (two inner electrodes), $T$ is the membrane thickness which is $0.0051 \mathrm{~cm}, 0.0144 \mathrm{~cm}$, and $0.0784 \mathrm{~cm}$ for Nafion 212, SPAEB_oleum $\left(\mathrm{SO}_{3} \% 65\right)$ and SPAEB membranes, respectively, and $W$ is the sample width.
Proton conductivities of the membranes at $80^{\circ} \mathrm{C}$ are calculated as $0.203 \mathrm{~S} / \mathrm{cm}(\mathrm{RH}=100 \%), 0.0059 \mathrm{~S} / \mathrm{cm}(\mathrm{RH}=$ $0 \%)$, and $0.0012 \mathrm{~S} / \mathrm{cm}(\mathrm{RH}=0 \%)$ for Nafion 212 , SPAEB, and SPAEB_oleum $\left(\mathrm{SO}_{3} \% 65\right)$, respectively. This result suggests that, as more sulfonic acid sites are incorporated into the membrane structure, the proton conductivity is decreased. Presence of sulfonic acid groups in the membrane structure decreases proton conductivity interacting with imidazole sites.

3.6. Fuel Cell Performance Test. Figure 11 shows the polarization and power density curves of SPAEB copolymer membrane. Average membrane thickness was measured as $0.0094 \mathrm{~cm}$. The highest power density of the membrane was measured as $23.7 \mathrm{~mW} \mathrm{~cm} \mathrm{~cm}^{-2}$ at $80^{\circ} \mathrm{C}$ without humidification.

\section{Conclusions}

SPAEB copolymer was synthesized successfully via nucleophilic aromatic polycondensation of the two monomers synthesized (SDCDPS and HPBI) and the commercial monomer DCDPS. Structures of monomers and the copolymer were confirmed by ${ }^{1} \mathrm{H}$ NMR and FTIR analysis. TGA analyses showed that as the degree of disulfonation is increased thermal stability of the copolymer is increased due to doublebonds and hydrogen bonds of sulfone groups. According to results of proton conductivity tests, as the degree of disulfonation increases, proton conductivity of the membranes decreases. Sulfonic acid groups prevent proton conduction from interacting with imidazole groups. Single cell performance test result shows that SPAEB membranes can be used as a polymer electrolyte membrane.

Since cost of PBI synthesis is quite high, SPAEB copolymer membrane, which includes a cheaper component poly(arylene ether), reduces the cost of the synthesis. There can be further researches to enhance the fuel cell performance of SPAEB membranes.

\section{Competing Interests}

The authors declare that they have no competing interests. 


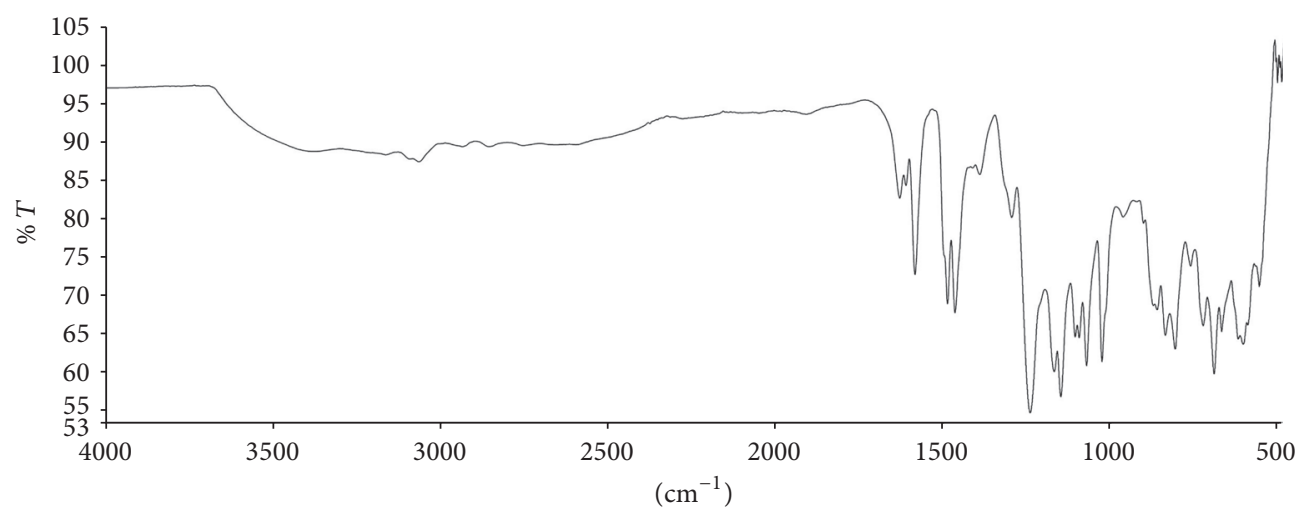

FIGURE 8: FTIR spectrum of SPAEB copolymer membrane.

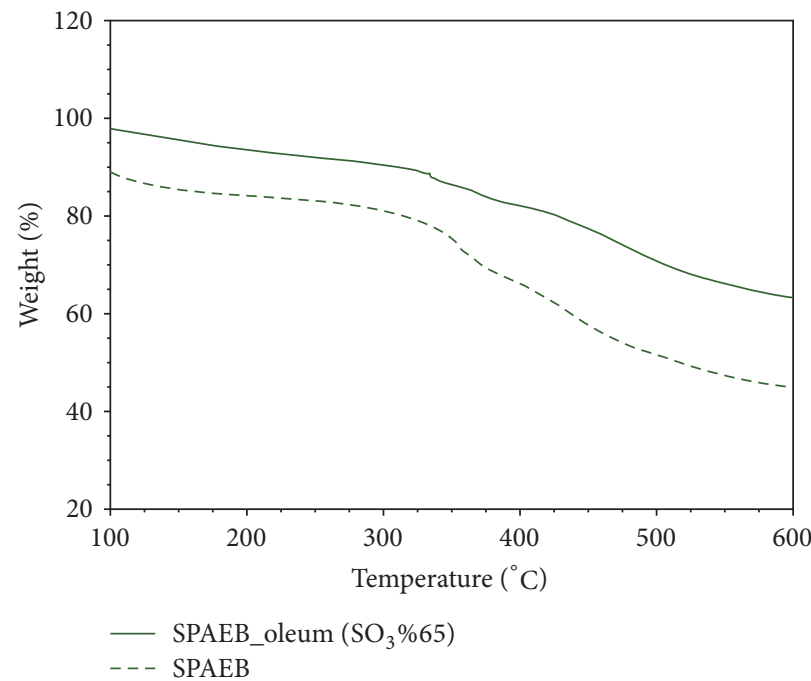

Figure 9: TGA curves of the SPAEB and SPAEB_oleum $\left(\mathrm{SO}_{3} \% 65\right)$ copolymers.

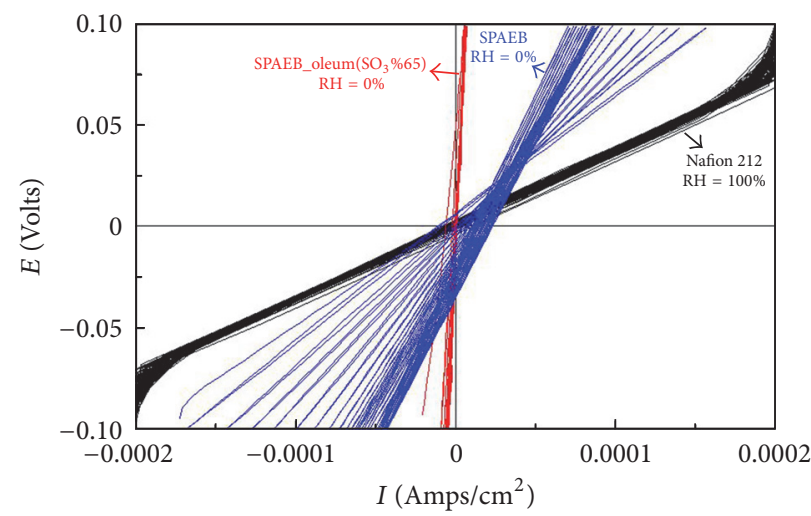

FIGURE 10: Voltage versus current graphs of SPAEB_oleum $\left(\mathrm{SO}_{3} \% 65\right)$, SPAEB, and commercial Nafion 212 membranes. 


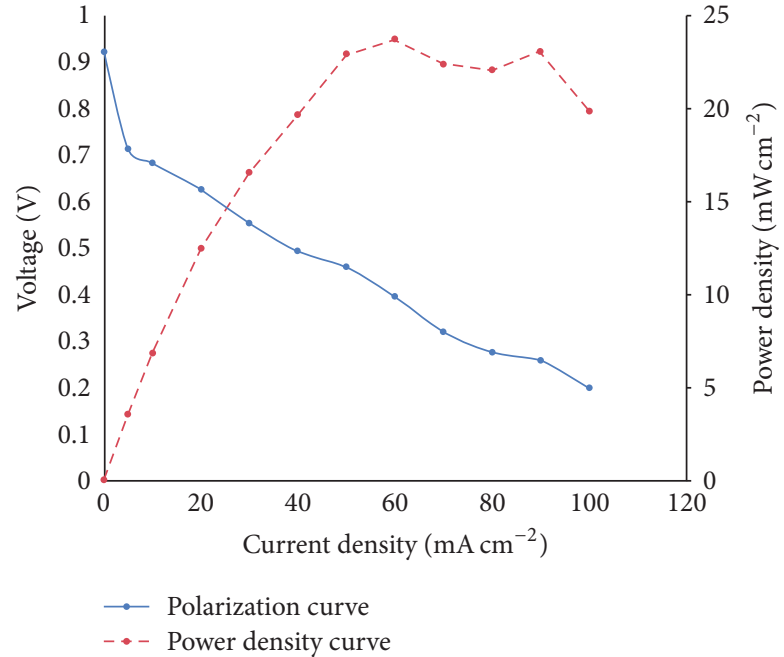

FIGURE 11: Polarization and power density curves of SPAEB copolymer membrane.

\section{Acknowledgments}

This research was supported by Anadolu University Scientific Research Projects Committee (Project no. 1206F102).

\section{References}

[1] L. Carrette, K. A. Friedrich, and U. Stimming, "Fuel cells: principles, types, fuels, and applications," ChemPhysChem, vol. 1, no. 4, pp. 162-193, 2000.

[2] Y. Qi, Y. Gao, S. Tian et al., "Synthesis and properties of novel benzimidazole- containing sulfonated polyethersulfones for fuel cell applications," Journal of Polymer Science, Part A: Polymer Chemistry, vol. 47, no. 7, pp. 1920-1929, 2009.

[3] Y. Sakaguchi, A. Kaji, K. Kitamura et al., "Polymer electrolyte membranes derived from novel fluorine-containing poly(arylene ether ketone)s by controlled post-sulfonation," Polymer, vol. 53, no. 20, pp. 4388-4398, 2012.

[4] Y. Sakaguchi, K. Kitamura, and S. Takase, "Isomeric effect of sulfonated poly(arylene ether)s comprising dihydroxynaphthalene on properties for polymer electrolyte membranes," Journal of Polymer Science, Part A: Polymer Chemistry, vol. 50, no. 22, pp. 4749-4755, 2012.

[5] E. P. Jutemar, S. Takamuku, and P. Jannasch, "Sulfonated poly(arylene ether sulfone) ionomers containing di- and tetrasulfonated arylene sulfone segments," Polymer Chemistry, vol. 2, no. 1, pp. 181-191, 2011.

[6] C.-H. Shen, S. L.-C. Hsu, E. Bulycheva, and N. Belomoina, "High temperature proton exchange membranes based on poly(arylene ether)s with benzimidazole side groups for fuel cells," Journal of Materials Chemistry, vol. 22, no. 36, pp. 1926919275, 2012.

[7] S.-W. Chuang, S. L.-C. Hsu, and C.-L. Hsu, "Synthesis and properties of fluorine-containing polybenzimidazole/montmorillonite nanocomposite membranes for direct methanol fuel cell applications," Journal of Power Sources, vol. 168, no. 1, pp. 172$177,2007$.

[8] P. Chen, X. Chen, Z. An, K. Chen, and K. Okamoto, "Quinoxaline-based crosslinked membranes of sulfonated poly(arylene ether sulfone)s for fuel cell applications," International Journal of Hydrogen Energy, vol. 36, no. 19, pp. 12406-12416, 2011.

[9] X. Li, Y. Yu, Q. Liu, and Y. Meng, "Synthesis and characterization of anion exchange membranes based on poly(arylene ether sulfone)s containing various cations functioned tetraphenyl methane moieties," International Journal of Hydrogen Energy, vol. 38, no. 25, pp. 11067-11073, 2013.

[10] J.-Y. Park, T.-H. Kim, H. J. Kim, J.-H. Choi, and Y. T. Hong, "Crosslinked sulfonated poly(arylene ether sulfone) membranes for fuel cell application," International Journal of Hydrogen Energy, vol. 37, no. 3, pp. 2603-2613, 2012.

[11] J.-H. Seol, J.-H. Won, K.-S. Yoon, Y. T. Hong, and S.-Y. Lee, "SiO2 ceramic nanoporous substrate-reinforced sulfonated poly(arylene ether sulfone) composite membranes for proton exchange membrane fuel cells," International Journal of Hydrogen Energy, vol. 37, no. 7, pp. 6189-6198, 2012.

[12] M. Han, G. Zhang, M. Li et al., "Considerations of the morphology in the design of proton exchange membranes: cross-linked sulfonated poly(ether ether ketone)s using a new carboxylterminated benzimidazole as the cross-linker for PEMFCs," International Journal of Hydrogen Energy, vol. 36, no. 3, pp. 2197-2206, 2011.

[13] Y. Li, M. Xie, X. Wang, D. Chao, X. Liu, and C. Wang, "Novel branched sulfonated poly(ether ether ketone)s membranes for direct methanol fuel cells," International Journal of Hydrogen Energy, vol. 38, no. 27, pp. 12051-12059, 2013.

[14] D. W. Seo, Y. D. Lim, S. H. Lee et al., "Preparation and characterization of sulfonated poly(tetra phenyl ether ketone sulfone)s for proton exchange membrane fuel cell," International Journal of Hydrogen Energy, vol. 37, no. 7, pp. 6140-6147, 2012.

[15] L. Gui, C. Zhang, S. Kang, N. Tan, G. Xiao, and D. Yan, "Synthesis and properties of hexafluoroisopropylidene-containing sulfonated poly(arylene thioether phosphine oxide)s for proton exchange membranes," International Journal of Hydrogen Energy, vol. 35, no. 6, pp. 2436-2445, 2010.

[16] L. P. Shen, G. Y. Xiao, D. Y. Yan, and G. M. Sun, "Sulfonated poly(arylene thioether ketone ketone sulfone)s for proton exchange membranes with high oxidative stability," E-Polymers, vol. 5, no. 1, pp. 321-330, 2005.

[17] S. J. Wang, Y. Z. Meng, A. R. Hlil, and A. S. Hay, "Synthesis and characterization of phthalazinone containing poly(arylene ether)s, poly(arylene thioether)s, and poly(arylene sulfone)s via a novel N-C coupling reaction," Macromolecules, vol. 37, no. 1, pp. 60-65, 2004.

[18] G. Bahlakeh and M. Nikazar, "Molecular dynamics simulation analysis of hydration effects on microstructure and transport dynamics in sulfonated poly(2,6-dimethyl-1,4-phenylene oxide) fuel cell membranes," International Journal of Hydrogen Energy, vol. 37, no. 17, pp. 12714-12724, 2012.

[19] T. Xu, D. Wu, S.-J. Seo, J.-J. Woo, L. Wu, and S.-H. Moon, "Proton exchange composite membranes from blends of brominated and sulfonated poly(2,6-dimethyl-1,4-phenylene oxide)," Journal of Applied Polymer Science, vol. 124, no. 4, pp. 3511-3519, 2012.

[20] X. Zhang, Z. Hu, Y. Pu et al., "Preparation and properties of novel sulfonated poly(p-phenylene-co-aryl ether ketone)s for polymer electrolyte fuel cell applications," Journal of Power Sources, vol. 216, pp. 261-268, 2012.

[21] S. Adanur and H. Zheng, "Synthesis and characterization of sulfonated polyimide based membranes for proton exchange membrane fuel cells," Journal of Fuel Cell Science and Technology, vol. 10, no. 4, Article ID 041001, 2013. 
[22] L. Akbarian-Feizi, S. Mehdipour-Ataei, and H. Yeganeh, "Survey of sulfonated polyimide membrane as a good candidate for nafion substitution in fuel cell," International Journal of Hydrogen Energy, vol. 35, no. 17, pp. 9385-9397, 2010.

[23] B.-K. Chen, T.-Y. Wu, C.-W. Kuo et al., "4,4/-Oxydianiline (ODA) containing sulfonated polyimide/protic ionic liquid composite membranes for anhydrous proton conduction," International Journal of Hydrogen Energy, vol. 38, no. 26, pp. 11321-11330, 2013.

[24] X. Liu, J. Yin, Y. Kong et al., "Electrical and mechanical property study on three-component polyimide nanocomposite films with titanium dioxide and montmorillonite," Thin Solid Films, vol. 544, pp. 352-356, 2013.

[25] J. W. Connell, J. G. Smith, and P. M. Hergenrother, "Properties and potential applications of poly(arylene ether benzimidazole)s," in High-Temperature Properties and Applications of Polymeric Materials, M. R. Ant, J. W. Connell, and H. L. N. McManus, Eds., vol. 603 of ACS Publications, pp. 186-199, American Chemical Society, Washington, DC, USA, 1995.

[26] Y. T. Hong, C. H. Lee, H. S. Park et al., "Improvement of electrochemical performances of sulfonated poly(arylene ether sulfone) via incorporation of sulfonated poly(arylene ether benzimidazole)," Journal of Power Sources, vol. 175, no. 2, pp. 724-731, 2008.

[27] F. Ng, D. J. Jones, J. Rozière, B. Bauer, M. Schuster, and M. Jeske, "Novel sulfonated poly(arylene ether benzimidazole) Cardo proton conducting membranes for PEMFC," Journal of Membrane Science, vol. 362, no. 1-2, pp. 184-191, 2010.

[28] J. Yu, M. Ree, T. J. Shin et al., "Miscibility behavior of polyimide (PI)/poly(arylene ether benzimidazole) (PAEBI) blends and its effects on the adhesion of PI/PAEBI/copper joints," Polymer, vol. 41, no. 1, pp. 169-177, 2000.

[29] P. M. Hergenrother, J. G. Smith Jr., and J. W. Connell, "Synthesis and properties of poly(arylene ether benzimidazole)s," Polymer, vol. 34, no. 4, pp. 856-865, 1993.

[30] B. R. Einsla, High temperature polymers for proton exchange membrane fuel cells [Ph.D. thesis], Virginia Polytechnic Institute and State University, Blacksburg, Va, USA, 2005.

[31] W. L. Harrison, F. Wang, J. B. Mecham et al., "Influence of the bisphenol structure on the direct synthesis of sulfonated poly(arylene ether) copolymers. I," Journal of Polymer Science, Part A: Polymer Chemistry, vol. 41, no. 14, pp. 2264-2276, 2003.

[32] M. Ueda, H. Toyota, T. Ouchi et al., "Synthesis and characterization of aromatic poly(ether sulfone)s containing pendant sodium sulfonate groups," Journal of Polymer Science, Part A: Polymer Chemistry, vol. 31, no. 4, pp. 853-858, 1993.

[33] F. Wang, M. Hickner, Q. Ji et al., "Synthesis of highly sulfonated poly(arylene ether sulfone) random (statistical) copolymers via direct polymerization," Macromolecular Symposia, vol. 175, no. 1, pp. 387-396, 2001.

[34] I. Blanco, L. Abate, F. A. Bottino, G. Cicala, and A. Latteri, "Dumbbell-shaped polyhedral oligomeric silsesquioxanes/polystyrene nanocomposites: the influence of the bridge rigidity on the resistance to thermal degradation," Journal of Composite Materials, vol. 49, no. 20, pp. 2509-2517, 2015.

[35] I. Blanco, F. A. Bottino, G. Cicala, A. Latteri, and A. Recca, "Synthesis and characterization of differently substituted phenyl hepta isobutyl-polyhedral oligomeric silsesquioxane/polystyrene nanocomposites," Polymer Composites, vol. 35, no. 1, pp. 151-157, 2014.
[36] S. Kaytakoglu and L. Akyalcin, "Optimization of parametric performance of a PEMFC, International Journal of Hydrogen Energy, vol. 32, no. 17, pp. 4418-4423, 2007.

[37] F. Samperi, C. Puglisi, T. Ferreri et al., "Thermal decomposition products of copoly(arylene ether sulfone)s characterized by direct pyrolysis mass spectrometry," Polymer Degradation and Stability, vol. 92, no. 7, pp. 1304-1315, 2007.

[38] F. Samperi, S. Battiato, C. Puglisi et al., "Synthesis and characterization of sulfonated copolyethersulfones," Journal of Polymer Science, Part A: Polymer Chemistry, vol. 48, no. 14, pp. 30103023, 2010.

[39] I. Blanco, G. Cicala, A. Latteri, A. Mamo, and A. Recca, “Thermal and thermo-oxidative degradations of poly(2,6-dimethyl1,4-phenylene oxide) (PPO)/copoly(aryl ether sulfone) P(ESESco-EES) block copolymers: a kinetic study," Journal of Thermal Analysis and Calorimetry, vol. 112, no. 1, pp. 375-381, 2013.

[40] I. Blanco, F. A. Bottino, G. Cicala, A. Latteri, and A. Recca, "A kinetic study of the thermal and thermal oxidative degradations of new bridged POSS/PS nanocomposites," Polymer Degradation and Stability, vol. 98, no. 12, pp. 2564-2570, 2013.

[41] L. Abate, V. Asarisi, I. Blanco, G. Cicala, and G. Recca, “The influence of sulfonation degree on the thermal behaviour of sulfonated poly(arylene ethersulfone)s," Polymer Degradation and Stability, vol. 95, no. 9, pp. 1568-1574, 2010. 

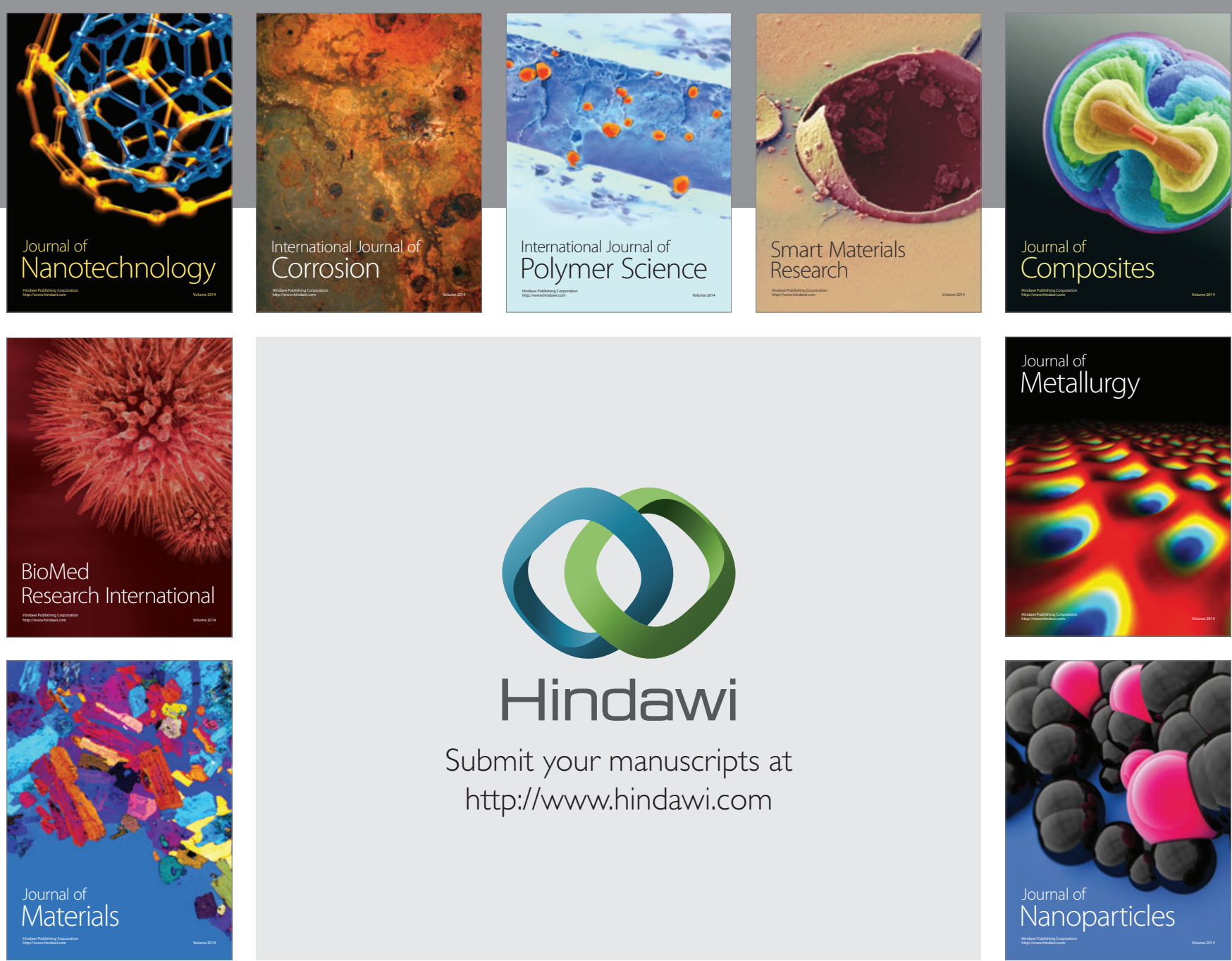

\section{Hindawi}

Submit your manuscripts at

http://www.hindawi.com

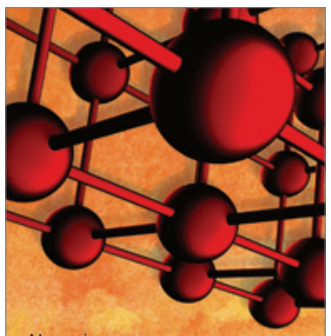

Materials Science and Engineering
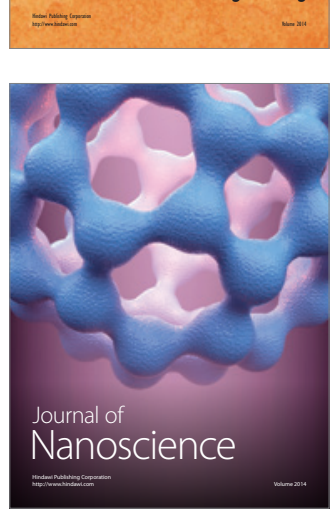
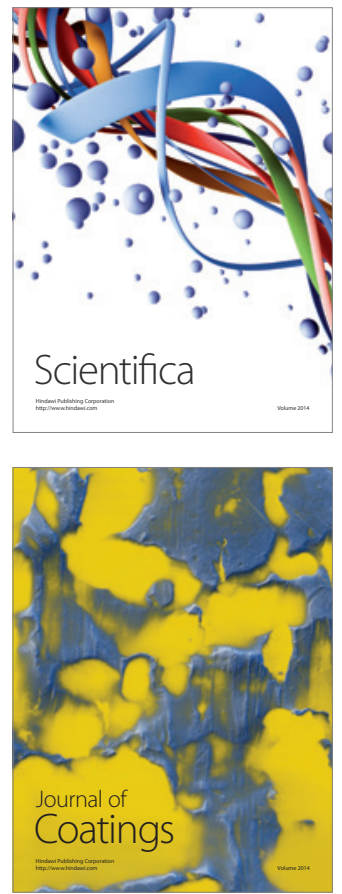
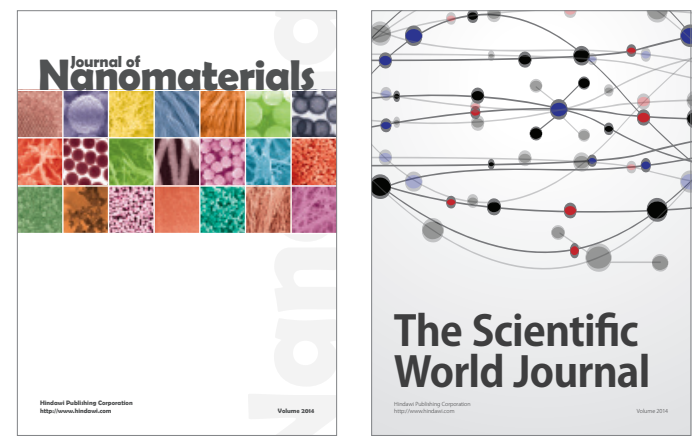

The Scientific World Journal
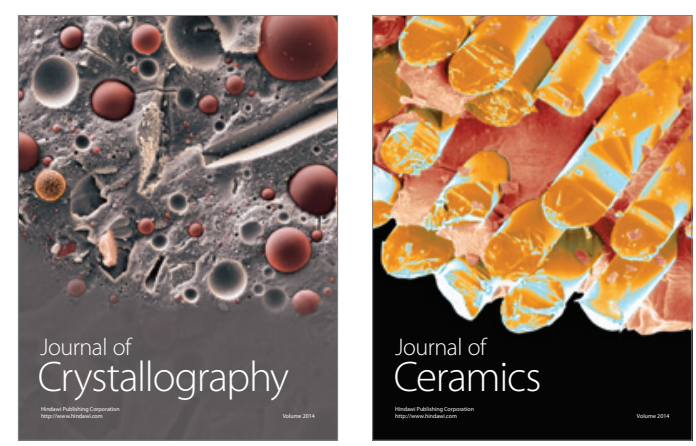
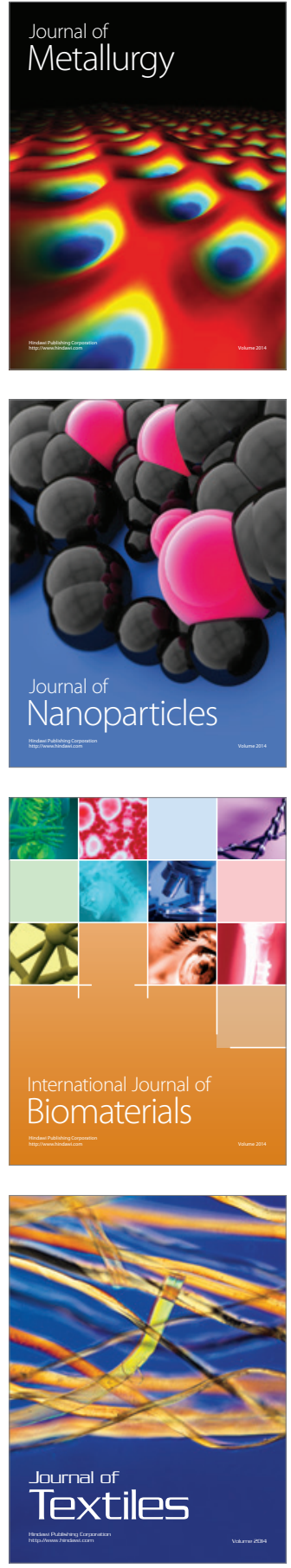